\title{
“CLIMATEGATE” UNDERMINED BELIEF IN GLOBAL WARMING AMONG MANY AMERICAN TV METEOROLOGISTS
}

by Edward Maibach, James Witte, and Kristopher Wilson

"Climategate" — the unauthorized release of, and news stories about, e-mails between climate scientists in the United States and United Kingdom - undermined belief in global warming and possibly also trust in climate scientists among TV meteorologists in the United States.

$\mathrm{T}$ elevision meteorologists are a potentially important source of informal climate change education in that a large majority of American adults watch local TV news (Pew Project for Excellence in Journalism 2010), viewers consider the weather segment to be the most important part of the TV newscast (Silcock et al. 2007; Smith 2007), and most members of the public consider TV weather

AfFILIATIONS: MAIBACH-Center for Climate Change Communication, George Mason University, Fairfax, Virginia; WITTE-Center for Social Science Research, George Mason University, Fairfax, Virginia; WILSON-School of Journalism, University of Texas, Austin, Texas

CORRESPONDING AUTHOR: Edward Maibach, Center for Climate Change Communication, George Mason University, MS 6A8, Fairfax, VA 22030

E-mail: emaibach@gmu.edu

The abstract for this article can be found in this issue, following the table of contents.

DOI:10.1175/2010BAMS3094.I

In final form 14 August 2010

C201I American Meteorological Society reporters to be a trusted source of information about global warming (Leiserowitz et al. 2009, 2010a). As a source of information about global warming, more American adults trust television weather reporters (56\%) than trust the mainstream news media (36\%), religious leaders (45\%), or various political leaders [Barack Obama (51\%), Al Gore (47\%), Sarah Palin (36\%), and Arnold Schwarzenegger (35\%)]; only scientists $(74 \%)$ are a more trusted source of global warming information than TV weather reporters (Leiserowitz et al. 2010a).

The opportunity for local television weathercasters to educate the public about climate change extends well beyond the weather segment to include story reporting on air and on station Web sites, blogging, and community presentations. Often, weathercasters are the only person in their newsroom with any science training. By default, many are expected to cover a wide range of science topics beyond their specialty of meteorology (Wilson 2008). The American Meteorological Society (AMS), one of meteorology's primary professional organizations, seeks to institutionalize this role by promoting their members as "station scientists" who are then expected to comment on a 
variety of science topics (American Meteorological Society 2010).

Climate change is one of the science topics most frequently discussed by local TV weathercasters (Wilson 2008). A significant minority, however, hold beliefs that conflict with the scientific consensus about climate change (Wilson 2002, 2008, 2009). For example, nearly a third (29\%) of AMS weathercasters surveyed agreed with the provocative assertion made by a prominent TV weathercaster that "global warming is a scam"; a larger proportion (41\%) indicated that their primary obstacle to reporting on the topic was "too much uncertainty" in climate science (Wilson 2009). An early study found that weathercasters' global warming attitudes and beliefs were more strongly predictive of their accurate knowledge of the science than were variables such as market size or the weathercaster's education, length of experience, seniority, or professional seals of approval (Wilson 2002), which potentially indicates that motivated reasoning was influencing interpretation of the scientific evidence of global warming at that time.

In late fall 2009, as we were making final preparations to conduct a national survey of television meteorologists, a story broke that soon came to be known as "Climategate." The unauthorized release of, and news stories about, e-mails between climate scientists in the United States and United Kingdom provided fodder for skeptics who saw in them a conspiracy to hide data and suppress dissenting voices. To evaluate the impact of Climategate on TV meteorologists we added additional questions to our survey. Specifically, we assessed the respondent's awareness of the story, attention to the story, and impact of the story on her/his belief as to whether climate change is or is not happening.

METHODS. Sample. In January and February 2010, using a Web-based method, we surveyed all broadcast TV members of the AMS and the National Weather Association (NWA) using member e-mail lists provided by the two professional associations. One month prior to the survey, both professional associations sent endorsement e-mails to their members, alerting them that they would be surveyed and encouraging them to participate. One week prior to the survey, participants received an e-mail from the principal investigator (EM) introducing them to the project and requesting their participation. At the start of the survey period, participants received an e-mail with a brief request to participate and a link to the Web-based survey (including the consent form). One week later, and again one week after that, participants who had not yet responded received additional e-mail requests to participate. Beginning 3 days after the final e-mail reminder, over the course of 1 week telephone calls were placed to nonrespondents who had known phone numbers to request their participation. All participants were offered $\$ 30$ to complete the approximately 20 -min survey.

Of the 1,408 names and e-mail addresses provided by AMS and NWA, 35 people were ineligible because we determined that they no longer worked as TV meteorologists, and $44 \mathrm{e}$-mail addresses proved to be incorrect (and, despite an active search, correct e-mail addresses could not be located). Therefore, the valid denominator of our sample was 1,373 . Fifty-nine of these people refused to participate, 743 did not respond, and 571 completed at least some portion of the survey, yielding a minimum response rate of $41.6 \%$ (which assumes that all nonrespondents were eligible to participate).

Using the American Association of Public Opinion Research's (AAPOR's) formula for estimating eligibility rate (e) among nonrespondents [refusals/ (refusals + known ineligibles); American Association of Public Opinion Research], we estimated the nonrespondent eligibility rate at $62.8 \%$. Applying AAPOR's adjustment for estimated eligibility among nonrespondents [(completed and partial interviews)/(completed and partial interview $)+$ (refusals) $+e$ (unknown eligibility)] yielded an adjusted response rate of $52.1 \%$.

Measures. Three variables were assessed specifically for this study. Both the awareness of and attention to Climategate by the respondents were assessed as independent variables. Using "yes," "no," and "don't know" as response options, awareness was ascertained with the following question: "Have you heard anything in the news recently about controversial e-mails between climate scientists in England and the US? Some news organizations have called the release of these e-mails 'Climategate."” Among the respondents indicating awareness of the story, attention to the story was assessed with the following question: "How closely have you followed the news stories about the controversial e-mails?" Response options were "very closely," "somewhat closely," "a little," and "not at all." To measure our dependent variable, the impact of the Climategate story, respondents who had followed the story a little or more closely were asked: "Would you say the news stories about the controversial e-mails made you: much more certain that global warming IS happening; somewhat more certain that global warming IS happening; somewhat more certain that global warming IS NOT happening; 
much more certain that global warming IS NOT happening; or they had no influence on my level of certainty."

We used several additional variables in the analysis. Trust in various scientific, professional, media, and other sources of climate change information, which were conceptualized as dependent variables, was assessed by having respondents rate their trust in various sources as follows: "strongly distrust," "somewhat distrust," "somewhat trust," or "strongly trust." Additional independent variables included belief in global warming ("What do you think? Do you think that global warming is happening?: Yes, No, Do not know"); level of professional certification [AMS Certified Broadcast Meteorologist seal (note: this is the most stringent level of certification available for broadcast meteorologists), AMS seal of approval, NWA seal of approval, or no seal of approval], gender (male or female), age $(<29,30-39,40-49,50-59$, and $60+$ ), and political ideology ("In general, do you think of yourself as: very conservative, somewhat conservative, moderate, somewhat liberal, very liberal?").

Using SPSS statistics software, we examined the distributions of all variables and cross-tabulated awareness, attention, and story impact by belief in global warming and political ideology. We also cross-tabulated trust in each information source by attention to Climategate (a little or more versus did not follow or was not aware of it), belief in global warming, and political ideology. Last, we conducted a logistic regression to assess the influence of professional certifications, belief in global warming, political ideology, age, and gender on the impact of the Climategate story (more certain global warming is not happening versus either no influence on certainty or greater certainty that global warming is happening).

RESULTS. A large majority (82.4\%) of the respondents had heard of the Climategate story. Awareness of the story did not vary significantly by belief in global warming but did by political ideology: $86.5 \%$ of conservatives and $82.9 \%$ of moderates as compared to $75.7 \%$ of liberals had heard of Climategate $\left(\chi^{2}=9.52\right.$ with 4 d.f.; $p=0.049$ ).

Among the respondents who were aware of the story, nearly all (93.6\%) followed the story "a little" or more closely (Table 1). Attention to the story varied by respondent's belief in global warming $\left(\chi^{2}=23.63\right.$ with 6 d.f.; $p<0.001)$ and their political ideology $\left(\chi^{2}\right.$ $=15.77$ with 6 d.f.; $p<0.05$ ). Respondents most likely to have followed the story "very closely" were those who did not believe in global warming (47.0\%) and political conservatives (37.4\%; Table 2).

Among the respondents who indicated they had followed the story "a little" or more closely, 55.8\% indicated that the story had no influence on their level of certainty, and $42.0 \%$ indicated the story made them somewhat $(26.1 \%)$ or much (15.9\%) more certain that global warming is not happening. Conversely, only

$2.3 \%$ indicated the story made them somewhat $(1.4 \%)$ or much (0.9\%) more certain that global warming is happening (Table 3). The impact of the story varied by respondent's belief in global warming $\left(\chi^{2}=\right.$ 108.59 with 4 d.f.; $p<0.001)$ and political ideology $\left(\chi^{2}=49.89\right.$ with 4 d.f.; $p<0.001)$. Respondents most likely to have indicated that the story made them much more certain that 
global warming is not happening were those who did not believe in global warming (42.3\%) and the political conservatives $(24.9 \%)$.

On a four-point scale (strongly distrust $=1$, somewhat distrust $=2$, somewhat trust $=3$, strongly trust $=4$ ), respondents rated how much they trust 11 potential sources of information about climate change, including climate scientists and the Intergovernmental Panel on Climate Change (IPCC), two sources that were frequently the focus of negative attention in the Climategate story. Overall, state climatologists and National Oceanic and Atmospheric Administration (3.1), peer-reviewed science journals and the National Weather Association conferences (3.0), and American Meteorological Society conferences and climate scientists (2.9) were the most trusted sources of information (Table 4). Respondents who had followed the Climategate story indicated significantly less trust for 8 of the 11 sources of information, including climate scientists and IPCC, than respondents who had not (all $p<0.05$ ) and had similar levels of trust for the other three sources: peer-reviewed journals, other weathercasters, and religious leaders. Respondents who do not believe in global warming indicated significantly less trust than those who do for 10 of the information sources, but indicated more trust for "other weathercasters" as an information source $(p<0.05)$. Political conservatives were significantly less trusting than liberals of nine of the information sources and more trusting of the following two sources: other weathercasters $(p<0.01)$ and religious leaders $(p<0.01)$.

To examine the possibility that the negative impact of the Climategate story was more pronounced among less credentialed meteorologists, we conducted a logistic regression using the impact of the story as the dependent variable (yes = somewhat or much more certain that global warming is not happening;

TABLE 2. Attention to Climategate stratified by belief in global warming and political ideology. Belief in global warming $\chi^{2}=23.63$ with 6 d.f.; $p<0.001$; political ideology $\chi^{2}=15.77$ with 6 d.f.; $p<0.05$.

\begin{tabular}{|l|c|c|c|c|c|c|c|}
\hline & Total & \multicolumn{2}{|c|}{ Belief in global warming $(\boldsymbol{n}=\mathbf{4 5 3})$} & \multicolumn{3}{|c|}{ Political ideology $(\boldsymbol{n}=\mathbf{4 4 3})$} \\
\hline $\begin{array}{c}\text { Followed the } \\
\text { story... }\end{array}$ & $\mathbf{( n = 4 5 5 )}$ & $\begin{array}{c}\text { Yes } \\
(\boldsymbol{n}=\mathbf{2 4 3})\end{array}$ & $\begin{array}{c}\text { Don't know } \\
(\boldsymbol{n}=\mathbf{9 3})\end{array}$ & $\begin{array}{c}\text { No } \\
(\boldsymbol{n}=117)\end{array}$ & $\begin{array}{c}\text { Liberal } \\
(\boldsymbol{n}=105)\end{array}$ & $\begin{array}{c}\text { Moderate } \\
(\boldsymbol{n}=159)\end{array}$ & $\begin{array}{c}\text { Conservative } \\
(\boldsymbol{n}=\mathbf{1 7 6})\end{array}$ \\
\hline Very closely & $30.3 \%$ & $23.9 \%$ & $28.0 \%$ & $47.0 \%$ & $17.0 \%$ & $31.0 \%$ & $37.4 \%$ \\
Somewhat closely & $37.6 \%$ & $39.9 \%$ & $39.8 \%$ & $29.9 \%$ & $44.3 \%$ & $41.1 \%$ & $31.8 \%$ \\
A little & $25.5 \%$ & $30.5 \%$ & $22.6 \%$ & $17.9 \%$ & $29.2 \%$ & $22.8 \%$ & $25.1 \%$ \\
Not at all & $6.4 \%$ & $5.8 \%$ & $9.7 \%$ & $5.1 \%$ & $9.4 \%$ & $5.10 \%$ & $5.6 \%$ \\
\hline
\end{tabular}

TABLE 3. Impact of Climategate stratified by belief in global warming and political ideology. Belief in global warming $\chi^{2}=108.59$ with 4 d.f.; $p<0.001$; political ideology $\chi^{2}=49.89$ with 4 d.f.; $p<0.001$.

\begin{tabular}{|l|c|c|c|c|c|c|c|}
\hline & Total & \multicolumn{2}{|c|}{ Belief in global warming $(\boldsymbol{n}=\mathbf{4 2 4})$} & \multicolumn{2}{|c|}{ Political ideology $(\boldsymbol{n}=\mathbf{4 1 5})$} \\
\hline $\begin{array}{l}\text { Would you say the } \\
\text { news stories about } \\
\text { the controversial } \\
\text { e-mails made you ... }\end{array}$ & $(\boldsymbol{n = 4 2 5 )}$ & $\begin{array}{c}\text { Yes } \\
(\boldsymbol{n}=\mathbf{2 2 9})\end{array}$ & $\begin{array}{c}\text { Don't know } \\
(\boldsymbol{n}=\mathrm{III})\end{array}$ & $\begin{array}{c}\text { No } \\
(\boldsymbol{n}=\mathbf{8 4})\end{array}$ & $\begin{array}{c}\text { Liberal } \\
(\boldsymbol{n}=\mathbf{9 6})\end{array}$ & $\begin{array}{c}\text { Moderate } \\
(\boldsymbol{n}=150)\end{array}$ & $\begin{array}{c}\text { Conservative } \\
(\boldsymbol{n}=169)\end{array}$ \\
\hline $\begin{array}{l}\text { They had no influence } \\
\text { on my level of certainty } \\
\text { or made me much/ } \\
\text { somewhat more certain } \\
\text { that global warming is } \\
\text { happening. }\end{array}$ & $58.1 \%$ & $75.1 \%$ & $53.6 \%$ & $26.1 \%$ & $85.4 \%$ & $56.7 \%$ & $42.6 \%$ \\
$\begin{array}{l}\text { Somewhat more certain } \\
\text { that global warming is } \\
\text { not happening } \\
\begin{array}{l}\text { Much more certain that } \\
\text { global warming is not } \\
\text { happening }\end{array}\end{array}$ & $26.1 \%$ & $19.2 \%$ & $38.1 \%$ & $31.5 \%$ & $11.5 \%$ & $30.0 \%$ & $32.5 \%$ \\
\hline
\end{tabular}


no $=$ no impact, or somewhat or much more certain that global warming is happening), and type of professional certification (none, NWA seal, AMS seal, AMS Certified Broadcast Meteorology seal), belief in global warming, political ideology, age (40 and under versus over 40), and gender as independent variables.

None of the professional credentials was significantly associated with negative impact of the story (NWA seal, $B=-0.10, p=$ not significant (n.s.); AMS seal, $B=-0.14, p=$ n.s.; AMS Certified Broadcast Meteorology seal, $B=-0.32, p=$ n.s.), nor was age (over $40, B=0.15, p=$ n.s.). Conversely, belief in global warming (no, $B=1.50, p<0.001$; do not know, $B=0.62, p=0.02$ ), political ideology (liberal, $B=-1.24, p<0.0001$; conservative, $B=0.37, p=0.09$ ), and gender (female, $B=-0.78, p<0.01$ ) were significantly associated with negative impact of the story.

Conservatives who followed the story were approximately $45 \%$ more likely than moderates, and liberals were $71 \%$ less likely than moderates, to report that Climategate made them more certain that global warming is not happening. Similarly, those respondents who indicated they "don't know" if global warming is happening and those who believe it is not happening were 1.8 and 4.5 times, respectively, more likely than those who believe it is happening to say that Climategate made them more certain that global warming is not happening. Female weathercasters, independent of their political ideology and belief in global warming, were $53.9 \%$ less likely than their male counterparts to report that Climategate made them more certain that global warming is not happening.

DISCUSSION. Our findings demonstrate that Climategate eroded global warming belief certainty among a large minority of TV meteorologists, at least temporarily. This erosion of belief certainty was most pronounced among politically conservative weathercasters and those who either do not believe in global warming or do not yet know, although some erosion in belief certain was also evident among politically liberal weathercasters and those who do believe in global warming. The story may also have eroded some TV weathercasters' trust in climate scientists and IPCC as sources of climate change information (although it is equally possible that weathercasters who were less trusting of climate scientists and IPCC were more likely to follow the story, and therefore the story had no impact on their level of trust).

It is important to note that this erosion of global warming belief certainty may or may not be long lasting. Our data were collected only $6-10$ weeks after the story first broke in mid-November 2009. At that

\begin{tabular}{|c|c|c|c|c|c|c|c|c|c|}
\hline \multirow[b]{2}{*}{$\begin{array}{l}\text { How much do you trust } \\
\text { or distrust the following } \\
\text { sources of information } \\
\text { about climate change? }\end{array}$} & \multirow{2}{*}{ 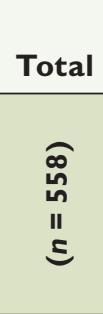 } & \multicolumn{2}{|c|}{$\begin{array}{l}\text { Followed } \\
\text { Climategate }\end{array}$} & \multicolumn{3}{|c|}{ Belief in global warming } & \multicolumn{3}{|c|}{ Political ideology } \\
\hline & & 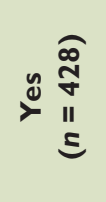 & $\stackrel{\stackrel{\text { }}{\text { I }}}{\text { II }}$ & 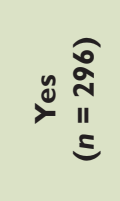 & 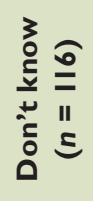 & 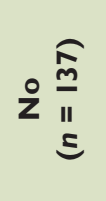 & 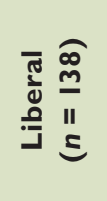 & 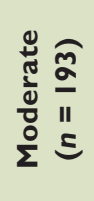 & 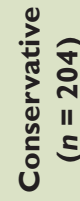 \\
\hline Peer-reviewed science journals & 3.0 & 3.0 & 3.1 & $3.2^{* *}$ & 2.9 & 2.6 & $3.3^{* *}$ & 3.0 & 2.8 \\
\hline Climate scientists & 2.9 & $2.8^{* *}$ & 3.2 & $3.2^{* *}$ & 2.8 & 2.3 & $3.3^{* *}$ & 2.9 & 2.7 \\
\hline IPCC & 2.3 & $2.2^{* *}$ & 2.7 & $2.7^{* *}$ & 2.2 & 1.6 & $2.9 * *$ & 2.4 & 1.8 \\
\hline NOAA/NWS & 3.1 & $3.0 * *$ & 3.3 & $3.3^{* *}$ & 3.0 & 2.8 & $3.3^{* *}$ & 3.1 & 2.9 \\
\hline State climatologists & 3.1 & $3.0^{*}$ & 3.2 & $3.2^{* *}$ & 3.1 & 2.8 & $3.2^{*}$ & 3.1 & 3.0 \\
\hline AMS conferences & 2.9 & $2.9 * *$ & 3.2 & $3.1^{* *}$ & 2.9 & 2.5 & $3.2^{* *}$ & 3.0 & 2.7 \\
\hline NWA conferences & 3.0 & $3.0^{*}$ & 3.1 & $3.1^{* *}$ & 3.0 & 2.8 & $3.1^{*}$ & 3.0 & 2.9 \\
\hline Other weathercasters & 2.5 & 2.5 & 2.4 & $2.4^{*}$ & 2.4 & 2.6 & $2.4^{*}$ & 2.4 & 2.6 \\
\hline Mainstream news media & 1.8 & $1.7 * *$ & 2.1 & $2.0 * *$ & 1.8 & 1.4 & $2.2^{* *}$ & 1.8 & 1.5 \\
\hline Political leaders & 1.4 & $1.3^{* *}$ & 1.5 & $1.5 * *$ & 1.4 & 1.2 & $1.5 * *$ & 1.4 & 1.3 \\
\hline Religious leaders & 1.6 & 1.6 & 1.7 & 1.5 & 1.6 & 1.5 & $1.4 * *$ & 1.5 & 1.7 \\
\hline
\end{tabular}


time, Climategate was still an active topic of discussion in the news, in media commentaries, and in the blogosphere. As a result, it is possible that we serendipitously captured the story's negative effect at its apex, with its impact waning over the ensuing months. The fact that the British and American climate scientists at the center of the controversy have since been cleared of all charges of wrongdoing would suggest that the impact of the story is likely to attenuate. Conversely, it is also possible that intentional efforts to sustain and amplify the controversy over time may prevent any such attenuation, or may even enhance the negative effect (Oreskes and Conway 2010). Further research is needed to assess the long-term impact of Climategate among weathercasters.

The motivated reasoning literature provides an important perspective on our findings. This literature makes clear that people are not dispassionate consumers of information. People's motivational states-their wishes and preferences-influence what information they choose to see, how they evaluate the information, and the conclusions they draw from it (Dawson et al. 2006; Ditto and Lopez 1992; Ditto et al. 1998; Kruglanski and Webster 1996; Kunda 1990; Zhao et al. 2010; Zhao 2009). People are inclined to accept information that is consistent with their preferred views at face value, and they may search only for information that supports their views. In contrast, people tend to be skeptical of information that contradicts their beliefs, and they look for reasons to reject such claims (Dawson et al. 2002; Kruglanski and Webster 1996). Because most evidence has flaws, inconsistencies, and ambiguities, people motivated to reject the evidence often can find a reason to do so. Such motivated reasoning has been shown to influence the evaluation of scientific evidence (Munro et al. 2004).

Motivated reasoning theorists, therefore, would predict that people who doubt the evidence of anthropogenic climate change are likely to interpret events such as Climategate as confirming and strengthening their previously held views. Conversely, people who accept the scientific consensus view-that anthropogenic climate change is occurring-are more likely to reject interpretations of Climategate as casting doubt on that evidence. These predictions are consistent with our findings here. Similar findings have been demonstrated among members of the general American adult population (Leiserowitz et al. 2010b).

As a public issue, climate change perceptions have become increasingly influenced by partisan status over the last decade or more (Dunlap and McCright 2008). Democrats' belief in climate change as real and human caused have risen steadily throughout the past decade, while Republicans' beliefs have declined. From this perspective, it is not surprising that TV weathercasters' political ideology, and their belief in global warming, would influence their response to Climategate. What is surprising, however, is that weathercasters who were more credentialed in the science of meteorology (as measured by their level of professional certification), on average, responded to the story in a manner similar to less scientifically credentialed weathercasters. In short, TV weathercasters appear to have responded to the Climategate story more through the lens of political ideology than through the lens of meteorology.

Our investigation of TV weathercasters was premised on the belief that TV weathercasters can potentially become an important source of climate change education for a broad cross section of Americans. While our findings reported elsewhere (Maibach et al. 2010) largely support this premise, we conclude from the current analysis that Climategate has been, at least temporarily, an impediment in efforts to encourage weathercasters to embrace the role of climate change educator.

There is nearly unanimous consensus among climate scientists that mean global temperatures are rising and that human activity is a significant contributing factor (Anderegg et al. 2010; Doran et al. 2009; U.S. Global Climate Change Research Program 2009). To help stakeholders understand this issue, climate science communicators must carefully consider the challenges inherent in sharing scientific evidence under conditions of motivated reasoning and should strive to find ways to build trust and mutual understanding with the full range of stakeholders, which includes people across the political spectrum and those who express doubt in the evidence.

ACKNOWLEDGMENTS. This research was supported by a National Science Foundation Grant DRL-0917566. We wish to thank Jagadish Thaker for his assistance with this research.

\section{REFERENCES}

American Association of Public Opinion Research, 2008: Standard definitions: Final dispositions of case codes and outcome rates for surveys. [Available online at www.aapor.org/Standard_Definitions/2852. htm.]

American Meteorological Society, 2010: Station scientist. [Available online at www.ametsoc.org/ stationscientist/index.html.] 
Anderegg, W. R. L., J. W. Prall, J. Harald, and S. Schneider, 2010: Expert credibility in climate change. Proc. Natl. Acad. Sci. USA, in press, doi: 10.1073/pnas.1003187107. [Available online at www. pnas.org/content/early/2010/06/04/1003187107.full. pdf+html.]

Dawson, E., T. Gilovich, and D. Regan, 2002: Motivated reasoning and the Wason selection task. Pers. Soc. Psychol. Bull., 28, 1379-1387.

— , K. Savitsky, and D. Dunning, 2006: Don't tell me, I don't want to know: Understanding people's reluctance to obtain medical diagnostic information. J. Appl. Soc. Psychol., 36, 751-768.

Ditto, P. H., and D. F. Lopez, 1992: Motivated skepticism: The use of differential decision criteria for preferred and nonpreferred conclusions. J. Pers. Soc. Psychol., 63, 568-584.

—, J. A. Scepansky, G. D. Munro, A. M. Apanovitch, and L. K. Lockhart, 1998: Motivated sensitivity to preference-inconsistent information. J. Pers. Soc. Psychol., 75, 53-69.

Doran, P., and M. Kendall Zimmerman, 2009: Examining scientific consensus on climate change. Eos, Trans. Amer. Geophys. Union, 90, 22-23.

Dunlap, R. E., and A. M. McCright, 2008: A widening gap-Republican and Democratic views on climate change. Environment, 50, 26-35.

Kruglanski, A. W., and D. M. Webster, 1996: Motivated closing of the mind: "Seizing" and "freezing." Psychol. Rev., 103, 263-283.

Kunda, Z., 1990: The case for motivated reasoning. Psychol. Bull., 108, 480-498.

Leiserowitz, A., E. Maibach, and C. Roser-Renouf, 2009: Climate change in the American mind: Americans' global warming beliefs, attitudes, policy preferences, and actions. Yale University and George Mason University, 55 pp. [Available online at www.climatechangecommunication.org/ resources_reports.cfm.]

- — $—$, and —_, 2010a: Climate change in the American mind: Americans' global warming beliefs and attitudes in January 2010. Yale University and George Mason University, 10 pp. [Availble online at http://environment.yale.edu/uploads/ AmericansGlobalWarmingBeliefs2010.pdf.]

,,,--- N. Smith, and E. Dawson, 2010b: Climategate, public opinion, and the loss of trust. SSRN, 24 pp. [Available online at http://papers. ssrn.com/sol3/Delivery.cfm/SSRN_ID1633932_ code1505444.pdf?abstractid $=1633932 \&$ mirid $=1$.]
Maibach, E., K. Wilson, and J. Witte, 2010: A national survey of television meteorologists about climate change: Preliminary findings. Center for Climate Change Communication, 24 pp. [Available online at www.climatechangecommunication.org/images/files/TV_Meteorologists_Survey_Findings_ (March_2010).pdf.]

Munro, G. D., S. P. Leary, and T. P. Lasane, 2004: Between a rock and a hard place: Biased assimilation of scientific information in the face of commitment. North Amer. J. Psychol., 6, 431-444.

Oreskes, N., and E. M. Conway, 2010: Merchants of Doubt. Bloomsbury Press, 368 pp.

Pew Project for Excellence in Journalism, cited 2010: State of the news media: An annual report on American journalism. 2009. [Available online at www.stateofthemedia.org/2009/narrative_localtv_ audience.php? media $=8 \&$ cat $=1 \# 1$.]

Silcock, B., D. Heider, and M. Rogus, 2007: Managing Television News: A Handbook for Ethical and Effective Producing. Lawrence Erlbaum, 272 pp.

Smith, D., 2007: Power Producer: A Practical Guide to TV News Producing. Radio Television and Digital News Association, 171 pp.

U.S. Global Climate Change Research Program, 2009: Global climate change impacts in the United States. U.S. Global Change Research Program, 196 pp. [Available online at http://downloads. globalchange.gov/usimpacts/pdfs/climate-impacts-report.pdf .]

Wilson, K., 2002: Forecasting the future: How television weathercasters' attitudes and beliefs about climate change affect their cognitive knowledge on the science. Sci. Commun., 24, 246-268.

— 2008 : Television weathercasters as potentially prominent science communicators. Public Understanding Sci., 17, 73-87.

— 2009: Opportunities and obstacles for television weathercasters to report on climate change. Bull. Amer. Meteor. Soc., 90, 1457-1465.

Zhao, X., 2009: Media use and global warming perceptions: A snapshot of the reinforcing spirals. Commun. Res., 36, 698-723.

- A. Leiserowitz, E. Maibach, and C. Roser-Renouf, 2010: Attention to science/environment news positively predicts and attention to political news negatively predicts global warming risk perceptions and policy support. J. Commun., in press. 